\title{
Vztah mezi nabídkovými a kupními cenami rodinných domů v Bř́eclavi
}

\author{
The Relationship between the Bid and the Purchase Prices \\ of the Family Houses in Břeclav
}

\author{
Marie Lorencováa ${ }^{*}$, Tomáš Lorenc ${ }^{b}$ \\ ${ }^{a}$ Vysoké učení technické v Brně, Ústav soudního inženýrství \\ ${ }^{b}$ Partners Financial Services
}

\begin{abstract}
Abstrakt
Článek pojednává o situaci na realitním trhu s rodinnými domy ve městě Břeclavi, resp. $v$ jeho čtyřech částech. Zejména je zde zaznamenán vývoj počtu inzerátů, dále vývoj nabídkových cen a jejich vztah s kupními cenami. Statisticky je vyhodnocena doba trvání nabídky a koeficient redukce na pramen ceny. Trh s rodinnými domy v dané lokalitě byl sledován na realitním serveru Sreality.cz a na serveru Českého úřadu zeměměřického a katastrálního cuzk.cz v období od 30. ř́ína 2017 do 10. listopadu 2019.
\end{abstract}

Klíčová slova: rodinný dům, realitní trh, nabídková cena, kupní cena, doba trvání nabídky, koeficient redukce na pramen ceny.

\section{1. ÚVOD}

Lokalita je považována za jeden ze stěžejních faktorů ovlivňujících výši tržní ceny, potažmo i tržní hodnoty či obvyklé ceny. A zcela opodstatněně. Při oceňování porovnáním je žádoucí použít objekty ze stejné lokality. Ne vždy jsou však okolnosti natolik příznivé, že zpracovatel ocenění disponuje vlastní kvalitní databází zadaného segmentu trhu právě pro konkrétní místo.

V současné době lze poměrně snadno získat cenové údaje u realizovaných prodejů na katastru nemovitostí, avšak tento přistup má i negativa. Např́klad u staveb je to absence fotodokumentace a popisů (pomocí různých leteckých a panoramatických snímků je možno si vytvořit představu o vnější podobě stavby, nikoli však o vnitřní situaci, údržbě a vybavení).

Vychází-li se při ocenění z realitní inzerce, která poskytuje fotodokumentaci i popisy, vždy chybí přesný údaj o výši kupní ceny. Toto lze řešit koeficientem redukce na pramen ceny. Jakou výši

\begin{abstract}
The paper deals with the situation on the real estate market with family houses in Břeclav, respectively in its four parts. In particular, the development of the number of advertisements, the development of bid prices and their relationship with purchase prices are recorded. The time on market and the reduction coefficient per source of price are statistically evaluated. The market for family houses in the locality was monitored on the real estate server Sreality.cz and on the server of the Czech Office for Surveying, Mapping and Cadastre cuzk.cz in the period from $30^{\text {th }}$ October 2017 to $10^{\text {th }}$ November 2019.
\end{abstract}

Keywords: family house, real estate market, bid price, purchase price, time on market, reduction coefficient of price source.

tohoto koeficientu použít při ocenění rodinných domů v Břeclavi je znázorněno $\mathrm{v}$ tomto článku. A to na základě dlouhodobého sledování realitní inzerce a dat z katastru nemovitostí.

Některé dílčí závěry uvedené $\mathrm{v}$ tomto článku jsou již obsaženy v diplomové práci spoluautora článku s názvem ,Analýza rozhodujících vlivi̊ na obvyklou cenu vybraných rodinných domů v Břeclavi “. [1]

\section{SOUČASNÝ STAV POZNÁNÍ}

Koeficient redukce na pramen ceny, někdy také nazývaný koeficient redukce na zdroj ceny, znázorňuje změnu ceny v průběhu trvání nabídky; číselně jej lze vyjádřit jako podíl kupní a nabídkové ceny. Tato definice pak platí v celém článku.

Znalci a odhadci při oceňování porovnávací metodou v případě znalosti pouze nabídkových cen obvykle používají koeficient redukce na pramen ceny v rozmezí od 0,85 do 0,95 . 
V rozsáhlé publikaci „, Teorie a praxe oceňování nemovitých věci “ z roku 2016 se uvádí, že ,zjištěni koeficientu vyžaduje průběžné pravidelné sledování inzerce, zejména změn požadované ceny“. U konkrétního př́kladu je použit koeficient redukce na pramen ceny 0,85 . [2]

Zbyněk Zazvonil v knize ,, Odhad hodnoty nemovitosti “ z roku 2012 zmiňuje, že použití inzerovaných nabídkových cen může být východiskem v př́padě, kdy se hodnotitel dostane do informační nouze, tj. vhodných realizovaných cen je málo. Ke konkrétní výši koeficientu vysvětluje, že „, Cenový rozdíl bývá v každém segmentu trochu jiný a je závislý předevšim na strategiich jednotlivých realitních kanceláriri". [3]

Mezi základní údaje pro porovnání řadí Petr Ort v knize „Oceňování nemovitostí - moderní metody a přistupy“ z roku 2013 i druh transakce (prodej, dražba/aukce, nabídka atd.). Zatímco u prodeje většinou není nutná korekce, u nabídky je korekce nutná vždy. Dále je zde popsáno, že: „Většina inzerentů požadovanou částku spíše nadsadi o desetinu až pětinu reálné hodnoty “. [4]

Změna mezi skutečnou prodejní cenou rodinného domu a cenou, kterou navrhne realitní makléŕ po znalosti představ prodávajícího a která se objeví v inzerátech, je sledována i v zahraničí. Procentuální vyjádření poměru těchto dvou cen může dosahovat jak hodnot nižších než $100 \%$ (transakce dopadla příznivěji pro kupujícího), tak vyšších než $100 \%$ (transakce dopadla příznivěji pro prodávajícího). Např. ve městě Tampa Bay na Floridě realitní kanceláře v roce 2019 dosáhly v průměru 94 až $96 \%$ z konečných inzerovaných cen. [5]
Disertační práce Martina Cupala z roku 2010 „,Vliv koeficientu redukce na zdroj ceny na výsledný index odlišnosti při komparativni metodě oceňování nemovitosti “ přináší zpřesnění a rozšíření hodnot koeficientu redukce na pramen ceny oproti odborné praxi, kdy se většinou v té době paušálně brala hodnota 0,85 . Pro kategorii rodinný dům ve městě v Jihomoravském kraji, kam patří i město Břeclav, byla vytvořena pomocí sjednocení výsledných hodnot makroanalýzy a mikroanalýzy hodnota koeficientu redukce na zdroj ceny ve výši 0,9293. [6]

V roce 2018 publikovali Tereza Opálková a Martin Cupal článek „Vývoj cen nemovitostí od nabídky do uskutečnění transakce a ověřeni diferencí u porovnávacího způsobu ocenéní". Při vyhodnocení 105 realizovaných prodejů rodinných domů v okrese Brno-venkov (získaných sběrem dat od 12. března 2017 do 31 . prosince 2017) byl dosažen koeficient redukce na zdroj ceny 0,89 a průměrná doba trvání nabídky 126 dnů. [7]

\section{SBĚR DAT}

$\mathrm{V}$ rámci podkladů pro diplomovou práci na téma „Analýza rozhodujicich vlivu na obvyklou cenu vybraných rodinných domů v Břeclavi “ " [1] byl od 30. ŕŕjna 2017 do 30. dubna 2019 intenzivně sledován jak realitní server Sreality.cz, tak server Českého úřadu zeměměřického a katastrálního cuzk.cz. Tato data byla následně doplněna o poznatky z období od 9. ř́jna 2019 do 10. listopadu 2019.

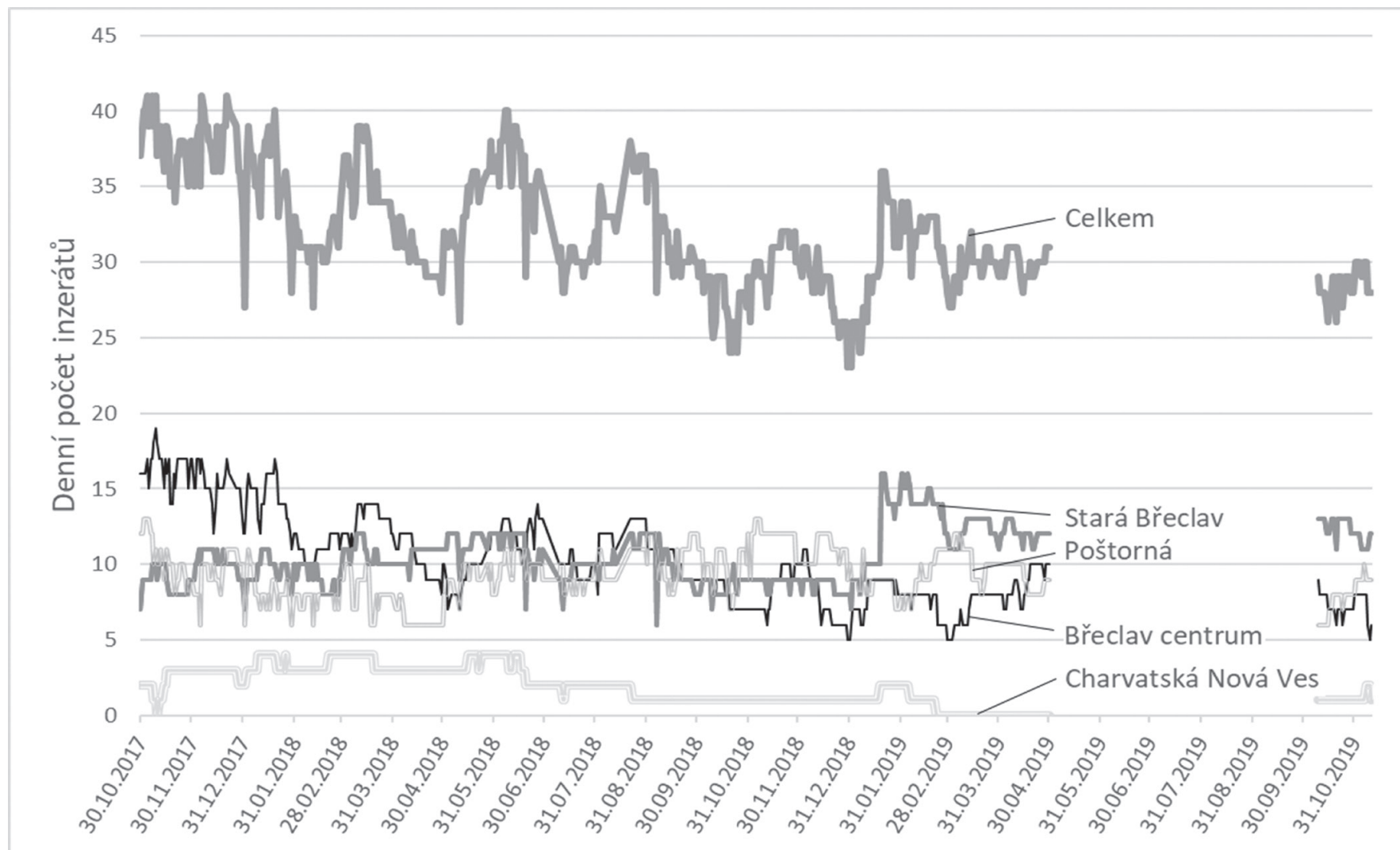

Obr. 1 Vývoj počtu inzerátů (zdroj: vlastní, zpracováno na základě dat z Sreality.cz [8]).

Fig. 1 The development of the number of advertisements. 
Tab. 1 Přehled počtů inzerátů a rodinných domů (zdroj: vlastní, zpracováno na základè dat z Sreality.cz [8] a cuzk.cz [9]). Tab. 1 The overview of the number of advertisements and the family houses.

\begin{tabular}{|c|c|c|c|c|c|}
\hline Oblast & $\begin{array}{l}\text { Břeclav } \\
\text { centrum }\end{array}$ & Stará Břeclav & Poštorná & Charvatská Nová Ves & $\begin{array}{l}\text { Město Břeclav } \\
\text { jako celek }\end{array}$ \\
\hline Počet inzerátů rodinných domů & 48 & 42 & 47 & 7 & 144 \\
\hline Počet nabízených rodinných domů & 39 & 33 & 32 & 7 & 111 \\
\hline Počet vyhodnotitelných nabízených rodinných domů & 34 & 17 & 25 & 4 & 80 \\
\hline Počet prodaných rodinných domů & 25 & 13 & 21 & 3 & 62 \\
\hline
\end{tabular}

V posledních dvou, třech letech, tj. i v obdobích, kdy byla sbírána data, byly v České republice nízké úrokové sazby a docházelo k růstu životní úrovně.

\subsection{Sběr dat $\mathrm{z}$ realitní inzerce}

Ve sledovaných dvou obdobích byl téměř každý den zaznamenáván počet inzerovaných nabídek rodinných domů v Břeclavi. V prvním období činil průměrný denní počet inzerátů 32. Nejméně nabídek bylo dne 1. ledna 2019, pouhých 23. Nejvyšší počet nabídek, tj. 41, byl dosažen ze začátku sledovaného období, 3. a 6. listopadu 2017. Ve druhém sledovaném období průměrný denní počet inzerátů klesl na 28. V rámci celého okresu Břeclav tvoří nabídky rodinných domů k prodeji ve městě Břeclav asi jednu šestinu.

Mezi inzeráty se občas objevily i inzeráty o rodinných domech $\mathrm{v}$ exekucích. Tyto nebyly dále zkoumány a z databáze byly vyloučeny. Stejně tak tomu bylo u budov, které byt' byly realitními makléři nazývány rodinnými domy, podmínky pro tento typ stavby nesplňovaly, většinou se jednalo o komerční budovy.

U každého inzerátu byla zaznamenána počáteční nabídková cena rodinného domu, dále bylo denně sledováno, zda došlo k jejímu poklesu či zvýšení, případně zda zůstala ve stejné výši. V případě, kdy v inzerátu cena chyběla, byl kontaktován realitní maklér̆ a ve většině př́ípadů byla nabídková cena zjištěna.

Rodinné domy byly rozděleny do 4 oblastí, první oblast je označována jako Břeclav centrum. Jedná se o katastrální území Břeclav bez části Stará Břeclav, která tvoří samostatnou (druhou) oblast. Třetí oblastí je Poštorná, která odpovídá katastrálnímu území Poštorná. Poslední (čtvrtou) je oblast Charvatská Nová Ves, kterou je stejnojmenné katastrální území. Nejméně nabídek rodinných domů bylo vždy v Charvatské Nové Vsi. Na počátku průzkumu bylo výrazně více nabídek pro oblast Břeclav centrum, ty však pozvolna ubývaly a zhruba v polovině prvního sledovaného období se počty pro Břeclav centrum, Starou Břeclav i Poštornou téměř vyrovnaly. Od poloviny ledna 2019 se nejvíce domů nabízelo ve Staré Břeclavi a tak tomu zůstalo až do konce prvního sledovaného období, i v průběhu druhého sledovaného období. Viz obr. 1.

\subsection{Sběr dat z Českého úřadu zeměměřického a katastrálního}

Každý rodinný dům, který se objevil v realitní inzerci, pokud to bylo reálné, byl dohledán na mapových serverech a na stránkách Českého úřadu zeměměřického a katastrálního. V prŕípadě, že rodinný dům z realitní inzerce zmizel, bylo na stránkách cuzk.cz sledováno, zda došlo k jeho prodeji. U prodaných rodinných domů byly zjištovány kupní ceny a data provedení vkladu na katastru nemovitostí.

\section{VÝSLEDKY SLEDOVÁNÍ REALITNÍHO TRHU}

Celkově lze nabídku rodinných domů k prodeji v Břeclavi hodnotit jako rozmanitou. Nalézt je zde možno domy umístěné v samotném centru i na úplném okraji města, domy různé velikosti a dispozice, ale i domy rozlišného stavebně technického stavu.

V prvním sledovaném období se na realitním serveru vyskytlo celkem 144 inzerátů rodinných domů. Stejný rodinný dům byl však někdy obsahem dvou i více inzerátů, pokaždé u jiné realitní kanceláře. Celkový počet nabízených domů je tedy nižší, a sice 111.

Pozn. Rodinné domy, které byly nabizeny po 30. dubnu 2019, včetně domů nabizených pouze ve druhém sledovaném období, nejsou předmětem dalšího zkoumání. K těmto domům nebyly prozatím zajištěny všechny požadované podklady a údaje.

Do dále uvedené kategorie vyhodnotitelných nabízených rodinných domů nebyly zařazeny zejména rozestavěné domy, domy k demolici, projekty rodinných domů (což ve Staré Břeclavi tvořilo asi polovinu objektů), domy s nezjištěnou nabídkovou cenou a domy, které se nepodařilo identifikovat.

Z nabízených (vyhodnotitelných) domů bylo na konci druhého sledovaného období, tj. k datu 10. listopadu 2019, prodáno celkem 62 rodinných domů. $Z$ tab. 1 je zřejmá situace nejen celkově pro město Břeclav, ale i pro jednotlivé oblasti.

\subsection{Doba trvání nabídky}

Poměrně častým trendem se stalo, že inzerát byl nějakou dobu zveřejněn, následovalo jeho stažení a po nějakém čase opětovné nasazení. Některé domy se nabízely i více než 2 roky. Jedním z nich byla luxusní vila s nadstandardním vybavením v centru Břeclavi přibližně za 11 mil. Kč. Nejkratší doba inzerování rodinného domu byla 1 den, jednalo se rodinný dům v Poštorné, nabízený ve druhém sledovaném období.

U zkoumaných rodinných domů se nejstarší datum provedení vkladu na katastr nemovitostí datuje na 20. prosince 2017, nejnovější pak 23. října 2019.

V tab. 2 je uvedena doba trvání inzerování, doba trvání od zmizení inzerátu do vkladu na katastr nemovitostí a celkově doba trvání nabídky, tj. od zveřejnění inzerátu do vkladu na katastr nemovitostí, a to již pouze pro prodaných 62 rodinných domů.

Průměrně doba inzerování rodinných domů činí asi třetinu roku, zatímco doba od zmizení inzerátu do provedení vkladu na katastr nemovitostí je asi čtvrt roku. V průměru celkově doba od vložení inzerátu do data vkladu na katastr nemovitostí činí 232 dnů. Průměrné hodnoty pro jednotlivé části města se nijak výrazně neliší. Je však nutno poznamenat, že minimální a maximální doby trvání, zejména doby inzerování, jsou značně 
Tab. 2 Přehled dob trváni nabidky (zdroj: vlastní, zpracováno na základě dat z Sreality.cz [8] a cuzk.cz [9]). Tab. 2 The overview of the time on market.

\begin{tabular}{|c|c|c|c|c|c|c|}
\hline & Oblast & $\begin{array}{l}\text { Břeclav } \\
\text { centrum }\end{array}$ & Stará Břeclav & Poštorná & Charvatská Nová Ves & $\begin{array}{c}\text { Město Břeclav } \\
\text { jako celek }\end{array}$ \\
\hline \multirow{6}{*}{$\begin{array}{l}\text { Počet dnů } \\
\text { inzerování }\end{array}$} & Průměr & 115 & 162 & 155 & 121 & 139 \\
\hline & Medián & 87 & 192 & 119 & 34 & 101 \\
\hline & Minimum & 20 & 7 & 3 & 32 & 3 \\
\hline & Maximum & 312 & 443 & 413 & 296 & 443 \\
\hline & Výběrová směrodatná odchylka $s$ & 87,40 & 142,16 & 122,91 & 151,85 & 114,67 \\
\hline & Variační koeficient $V[\%]$ & 76 & 88 & 79 & 125 & 82 \\
\hline \multirow{6}{*}{$\begin{array}{l}\text { Počet dnů } \\
\text { od zmizení } \\
\text { inzerátu } \\
\text { do vkladu } \\
\text { na katastr } \\
\text { nemovitostí }\end{array}$} & Průměr & 92 & 86 & 102 & 63 & 93 \\
\hline & Medián & 88 & 70 & 100 & 64 & 86 \\
\hline & Minimum & 13 & 43 & 19 & 57 & 13 \\
\hline & Maximum & 285 & 266 & 237 & 68 & 285 \\
\hline & Výběrová směrodatná odchylka $s$ & 60,31 & 58,04 & 49,59 & 5,57 & 54,60 \\
\hline & Variační koeficient $V[\%]$ & 66 & 67 & 49 & 9 & 59 \\
\hline \multirow{6}{*}{$\begin{array}{l}\text { Počet dnů } \\
\text { od prvního } \\
\text { vložení inzerátu } \\
\text { do vkladu } \\
\text { na katastr } \\
\text { nemovitostí }\end{array}$} & Průměr & 207 & 248 & 257 & 184 & 232 \\
\hline & Medián & 186 & 275 & 262 & 100 & 194 \\
\hline & Minimum & 52 & 60 & 91 & 91 & 52 \\
\hline & Maximum & 524 & 507 & 520 & 360 & 524 \\
\hline & Výběrová směrodatná odchylka $s$ & 123,58 & 155,71 & 125,19 & 152,78 & 131,59 \\
\hline & Variační koeficient $V$ [\%] & 60 & 63 & 49 & 83 & 57 \\
\hline
\end{tabular}

Pozn. Doba inzerování může být u čtvrtiny domů delší, protože tyto byly pravděpodobně inzerovány již před zahájením sledování nabídek.

odlehlé. Průměry nejsou s ohledem na vysoké hodnoty směrodatné odchylky charakteristické pro daná čísla. Jedná se o nesourodé statistické soubory, což výstižně znázorňuje variační koeficient $V$ (podíl výběrové směrodatné odchylky $s$ a průměru, vyjádřený $\mathrm{v}$ procentech).

S ohledem na výskyt extrémních hodnot na jedné straně intervalu se jeví jako vhodnější použít pro charakteristiku typické hodnoty dat medián. Ten pro všechny tři případy dosahuje nižších hodnot a to přibližně o $17 \%$.

Průměrná celková doba trvání nabídky dosahuje téměr̆ dvojnásobné hodnoty oproti zjištění Terezy Opálkové a Martina Cupala v okrese Brno-venkov. [7]

\subsection{Koeficient redukce na pramen ceny}

Díky znalosti údajů, jak z inzerátů, tak z katastru nemovitostí, se podařilo vyjádřit změny mezi nabídkovými a kupními cenami rodinných domů. Jak je zřejmé z tab. 3, ne vždy se jednalo o snížení ceny (hodnoty nižší než 1 ), ale v několika případech došlo i k jejímu zvýšení (hodnoty vyšší než 1). Jednoznačná př́ǐina navýšení ceny však nebyla zjištěna.

U rodinného domu, u něhož byla doba od vložení inzerátu do vkladu na katastru nemovitostí nejdelší, nedošlo k největšímu snížení ceny. U domu s nejkratší dobou zůstala kupní cena ve stejné výši jako nabídková (počáteční i konečná). Největší snížení, a to o $50 \%$ od nabídkové ceny (počáteční i konečné) do kupní ceny, nastalo u domu určeného k celkové rekonstrukci v Poštorné. Většina dalších domů, u kterých došlo taktéž k velkému snížení ceny, byla obdobně v horším stavu, určena k rekonstrukci. Největší zvýšení, tj. o $30 \%$ od nabídkové ceny (počáteční i konečné) ke kupní ceně, bylo zaznamenáno u domu ve Staré Břeclavi, avšak prŕčina není zřejmá.

Charakteristika polohy v podobě aritmetického průměru i mediánu se výrazně neliší. Ve všech případech jsou variační koeficienty výrazně nižší než u výše uvedených dob trvání.

Snížení ceny rodinného domu v průběhu inzertní nabídky činí pro Břeclav $5 \%$. Změna mezi konečnou nabídkovou cenou a kupní cenou dosahuje jen $4 \%$.

Stěžejní je prostřední část tab. 3, znázorňující změnu od počáteční nabídkové ceny po kupní cenu. Pro prípadné vyloučení extrémních hodnot $\mathrm{z}$ databáze byl proveden pro tyto hodnoty Grubbsův test (parametrický statistický test). V jednom případě byla zamítnuta nulová hypotéza, a sice z databáze pro Starou Břeclav byl vyloučen rodinný dům s největším koeficientem redukce na pramen ceny $(1,30)$.

Průměrná hodnota koeficientu redukce na pramen ceny pro město Břeclav klesla po vyloučení extrémní hodnoty na 0,91 viz tab. 4.

Výsledná hodnota koeficientu redukce na pramen ceny se výrazně neodlišuje od hodnoty stanovené pro rodinné domy v okrese Brnovenkov v roce 2017, která činila 0,89. [7]

\section{ZÁVĚR}

V praxi je při oceňování porovnáním s obdobnými objekty, u nichž je známa pouze nabídková cena, používána výše koeficientu redukce na pramen ceny v rozmezí od 0,85 do 0,95 . Na základě vyhodnocení databáze rodinných domů, u nichž byla zjištěna jak 
Tab. 3 Přehled koeficientů znázorňujicich změnu nabídkových a kupních cen (zdroj: vlastní, zpracováno na základě dat z Sreality.cz [8] a cuzk.cz [9]).

Tab. 3 The overview of coefficients showing the change between bid and purchase prices.

\begin{tabular}{|c|c|c|c|c|c|c|}
\hline & Oblast & $\begin{array}{l}\text { Břeclav } \\
\text { centrum }\end{array}$ & Stará Břeclav & Poštorná & Charvatská Nová Ves & $\begin{array}{l}\text { Město Břeclav } \\
\text { jako celek }\end{array}$ \\
\hline \multirow{7}{*}{$\begin{array}{l}\text { Koeficient } \\
\text { znázorňující změnu } \\
\text { mezi počáteční } \\
\text { a konečnou } \\
\text { nabídkovou cenou }\end{array}$} & Průměr & 0,97 & 0,97 & 0,93 & 0,95 & 0,95 \\
\hline & Medián & 1,00 & 1,00 & 0,92 & 1,00 & 1,00 \\
\hline & Minimum & 0,69 & 0,83 & 0,73 & 0,84 & 0,69 \\
\hline & Maximum & 1,09 & 1,02 & 1,39 & 1,00 & 1,39 \\
\hline & Výběrová směrodatná odchylka $s$ & 0,09 & 0,06 & 0,15 & 0,09 & 0,11 \\
\hline & Variační koeficient $V$ [\%] & 9 & 6 & 16 & 9 & 12 \\
\hline & Počet domů & 25 & 11 & 19 & 3 & 58 \\
\hline \multirow{7}{*}{$\begin{array}{l}\text { Koeficient } \\
\text { znázorňující změnu } \\
\text { mezi počáteční } \\
\text { nabídkovou cenou } \\
\text { a kupní cenou }\end{array}$} & Průměr & 0,93 & 0,97 & 0,88 & 0,87 & 0,92 \\
\hline & Medián & 0,95 & 0,96 & 0,89 & 0,83 & 0,94 \\
\hline & Minimum & 0,62 & 0,80 & 0,50 & 0,81 & 0,50 \\
\hline & Maximum & 1,17 & 1,30 & 1,27 & 0,97 & 1,30 \\
\hline & Výběrová směrodatná odchylka $s$ & 0,13 & 0,13 & 0,16 & 0,09 & 0,14 \\
\hline & Variační koeficient $V$ [\%] & 14 & 13 & 18 & 10 & 15 \\
\hline & Počet domů & 25 & 13 & 21 & 3 & 62 \\
\hline \multirow{7}{*}{$\begin{array}{l}\text { Koeficient } \\
\text { znázorňující změnu } \\
\text { mezi konečnou } \\
\text { nabídkovou cenou } \\
\text { a kupní cenou }\end{array}$} & Průměr & 0,96 & 1,01 & 0,95 & 0,92 & 0,96 \\
\hline & Medián & 0,99 & 1,00 & 1,00 & 0,96 & 1,00 \\
\hline & Minimum & 0,62 & 0,89 & 0,50 & 0,83 & 0,50 \\
\hline & Maximum & 1,07 & 1,30 & 1,03 & 0,97 & 1,30 \\
\hline & Výběrová směrodatná odchylka $s$ & 0,09 & 0,10 & 0,12 & 0,08 & 0,10 \\
\hline & Variační koeficient $V$ [\%] & 9 & 10 & 13 & 9 & 10 \\
\hline & Počet domů & 25 & 11 & 19 & 3 & 58 \\
\hline
\end{tabular}

Pozn. Počty rodinných domů pro statistické vyhodnocení se liší. A to z toho důvodu, že u rodinných domů, u kterých byla nabídková cena zjištována př́mo u realitního makléře, nebylo možno vyhodnotit snížení od počáteční po konečnou nabídkovou cenu, ani snížení od konečné nabídkové ceny po kupní cenu.

Pozn. Koeficienty mohou být u čtvrtiny domů mírně odlišné, protože tyto byly pravděpodobně inzerovány již před zahájením sledování nabídek.

Tab. 4 Koeficient redukce na pramen ceny po úpravě (zdroj: vlastní, zpracováno na základě dat z Sreality.cz [8] a cuzk.cz [9]). Tab. 4 Reduction coefficient of price source after the adjustment.

\begin{tabular}{|c|c|c|c|c|c|c|}
\hline \multicolumn{2}{|c|}{ Oblast } & $\begin{array}{l}\text { Břeclav } \\
\text { centrum }\end{array}$ & Stará Břeclav & Poštorná & Charvatská Nová Ves & $\begin{array}{l}\text { Město Břeclav } \\
\text { jako celek }\end{array}$ \\
\hline \multirow{7}{*}{$\begin{array}{l}\text { Koeficient znázorňující } \\
\text { změnu mezi počáteční } \\
\text { nabídkovou cenou } \\
\text { a kupní cenou }\end{array}$} & Průměr & 0,93 & 0,94 & 0,88 & 0,87 & 0,91 \\
\hline & Medián & 0,95 & 0,96 & 0,89 & 0,83 & 0,92 \\
\hline & Minimum & 0,62 & 0,80 & 0,50 & 0,81 & 0,50 \\
\hline & Maximum & 1,17 & 1,07 & 1,27 & 0,97 & 1,27 \\
\hline & $\begin{array}{l}\text { Výběrová směrodatná } \\
\text { odchylka } s\end{array}$ & 0,13 & 0,08 & 0,16 & 0,09 & 0,13 \\
\hline & Variační koeficient $V$ [\%] & 14 & 9 & 18 & 10 & 14 \\
\hline & Počet domů & 25 & 12 & 21 & 3 & 61 \\
\hline
\end{tabular}


nabídková, tak i kupní cena, je možno konstatovat, že uvedené rozmezí bylo potvrzeno i pro současný realitní trh s rodinnými domy ve městě Břeclavi, resp. $v$ jednotlivých částech města.

\section{LITERATURA}

[1] LORENC, T. Analýza rozhodujicich vlivů na obvyklou cenu vybraných rodinných domů v Břeclavi. Brno, 2019. Dostupné také z: https://www.vutbr.cz/studenti/zav-prace/detail/108777. Diplomová práce. Vysoké učení technické v Brně, Ústav soudního inženýrství, Odbor znalectví ve stavebnictví a oceňování nemovitostí. 89 s., 29 s. příloh. Vedoucí práce Ing. Milada Komosná, Ph.D.

[2] BRADÁČ, A. a kol.: Teorie a praxe oceňováni nemovitých věcí. 1. vydání. CERM, Brno, 2016, 790 s. ISBN 978-80-7204-930-0.

[3] ZAZVONIL, Z. Odhad hodnoty nemovitostí. 1. vydání. Nakladatelství Ekopress, Praha, 2012, 454 s. ISBN 978-80-86929-88-0.
[4] ORT, P. Oceňování nemovitostí- moderní metody a př́stupy. 1. vydání. Leges, Praha, 2013, 176 s. ISBN 978-80-87212-77-9.

[5] JAMASON, L. Home Selling: What is a List-to-Sell Ratio? In: DWELL Real Estate [online]. 2019 [cit. 2020-03-19]. Dostupné z: https://www.dwellfl.com/2019/06/10/home-sellingwhat-is-a-list-to-sell-ratio/

[6] CUPAL, M. Vliv koeficientu redukce na zdroj ceny na výsledný index odlišnosti při komparativni metodè oceňování nemovitostí. Brno, 2010, 245 s., 42 s. prŕloh. Disertační práce na Ústavu soudního inženýrství Vysokého učení technického v Brně. Vedoucí disertační práce prof. Ing. Albert Bradáč, DrSc.

[7] OPÁLKOVÁ, T., CUPAL, M. Vývoj cen nemovitostí od nabídky do uskutečnění transakce a ověření diferencí u porovnávacího způsobu ocenění. In: Sborník přispěvki̊ konference Expert Forensic Science Brno 2018, Vysoké učení technické v Brně, Ústav soudního inženýrství, Brno, 2018, s. 407-412. ISBN 978-80-214-5600-6.

[8] Sreality.cz [online] 2019. Dostupné z: https://www.sreality.cz/.

[9] Český úřad zeměměřický a katastrální [online] 2019. Dostupné z: https://www.cuzk.cz/.

\section{Správná citace:}

LORENCOVÁ, M., Lorenc, T. Vztah mezi nabídkovými a kupními cenami rodinných domů v Břeclavi. Soudní inženýrství, 2020, 31(2), 41-46. DOI: http://dx.doi.org./10.13164/SI.2020.2.41. ISSN 1211-443X. 